Article

\title{
The Eyes of That Cow: Eating Animals and Theorizing Vegetarianism in James Joyce's Ulysses
}

\author{
Peter Adkins
}

School of English, University of Kent, Canterbury CT2 7NZ, UK; p.adkins@kent.ac.uk

Received: 25 May 2017; Accepted: 26 June 2017; Published: 4 July 2017

\begin{abstract}
At the end of the nineteenth century more than half of Ireland's entire land surface was being used for the raising of livestock, most of which was transported through Dublin on its way to England to be slaughtered and eaten. The same period saw the development of a new social phenomena of vegetarianism amongst Ireland's intellectuals and literary figures. This article focuses on James Joyce's portrayal of livestock, meat and vegetarianism in Ulysses, examining how the novel engages with the politics of cattle raising, the emergence of industrialized animal slaughter and the ethics of meat eating at the turn of the twentieth century. Attending to the ways in which Joyce both historicizes and theorizes the lives of animals and the production of meat, this article places Ulysses in dialogue with recent writings on animal ethics by Jacques Derrida and J. M. Coetzee and the emergence of what is being termed "vegan studies" to suggest a vegetarian reading of Joyce's novel.
\end{abstract}

Keywords: James Joyce; Ulysses; animal studies; modernism; vegetarianism; vegan studies; literary ethics; meat; J. M. Coetzee; Jacques Derrida

\section{Introduction}

On the 12 March 1891 the Dublin Vegetarian Society opened the Sunshine Dining Rooms at 48 Grafton Street, the Irish capital's first vegetarian restaurant. An unsigned notice in The Irish Times two days later offered an account of the 'extremely well patronised' opening, predicting that if 'the question of vegetarianism has not to any great extent excited public discussion in Dublin up to the present, in all probability there will arise a school of Dubliners who advocate the use of the simple fruits of the earth in preference to the "flesh of bullocks, sheep or goats" (The Irish Times 1891, p. 7). In James Joyce's Ulysses (1922), set some thirteen years after the opening, the Sunshine Rooms makes an unnamed appearance. Leopold Bloom, walking toward Grafton Street, passes the revivalist poet George 'A.E.' Russell and an unnamed female companion '[c]oming from the vegetarian' (Joyce 1986, p. 136). Bloom, gloomy with hunger, finds the 'high figure in homespun' clothes to confirm his prejudice that vegetarianism is the domain of 'literary ethereal people' whose absurd theosophical doctrines expound the notion that if you 'eat a beefsteak' the 'eyes of that cow will pursue you through all eternity' (Joyce 1986, pp. 135-36). Joyce's novel, with its benefit of hindsight, provides a rather pessimistic rejoinder to The Irish Times' prediction of an emergent vegetarian class. For Bloom, who is open-minded enough to have once tried a meatless diet of 'weggebobbles and fruit' but disliked both the 'salty' taste of the dishes and the '[w]indandwatery' effect on his bowels, it is a juicy 'rumpsteak' rather than a dry 'nutsteak' that he desires for lunch. (Joyce 1986, p. 136).

As this short scene in Ulysses attests, where a school of vegetarian Dubliners had emerged was amongst the writers, artists and intellectuals associated with cultural revivalism at the turn of the twentieth century. James Gregory's history of nineteenth century vegetarianism emphasises the fact that although the word "vegetarian" entered public usage in the same period that animal welfare concerns were also becoming more prominent, vegetarianism itself was associated with broader social movements, including temperance, sanitation reform and spiritualism (Gregory 2007, pp. 1, 5). Indeed, 
as demonstrated in Bloom's observation that 'They say its healthier' (Joyce 1986, p. 136), there were often corporeal rather than ethical motives behind vegetarianism. In Dublin, vegetarianism was publicly represented by an 'advanced circle' of middle-class, mainly Anglo-Irish intellectuals affiliated with the Celtic revival. Figures such as W.B. Yeats, George Russell, James H. Cousins, Margaret Cousins, and the Sheehy-Skeffingtons would gather at Dublin's vegetarian restaurant to discuss the militant Irish Women's Franchise League, anti-smoking measures and theosophy (Gregory 2007, pp. 60-61). For the revivalists, vegetarianism did not primarily reflect a concern with animal welfare, so much as it was a spiritual and political practice. While Gregory incorrectly includes Joyce within this group of vegetarians, Joyce nonetheless did know, to a varying degree, all of the aforementioned figures and as a young writer had been encouraged by both Yeats and Russell to ally himself with the Revival (Ellmann 1983, pp. 99-104). Joyce's disinclination to closely affiliate himself with the cultural movement, especially what he saw as its mysticism, was galvanized in a rejection of the vegetarianism that he perceived to be central to the group's philosophy. Writing to his brother, Stanislaus, in 1903, Joyce explained that ' $[\mathrm{w}]$ ords cannot measure my contempt for AE ... and his spiritual friends' and that he wanted to 'damn Russell, damn Yeats, ... damn free-thinkers, damn vegetable verse and double damn vegetable philosophy' (Joyce 1966, p. 27).

Joyce's distaste for what he saw as the high-minded vegetarianism of Russell is evident in Bloom's run-in with him in Ulysses. Yet, while Joyce is disparaging in his portrayal of Russell, over the course of the novel, a more nuanced and less overtly antagonistic dialogue with vegetarianism emerges. This article will examine the ways in which Ulysses engages with questions of animal ethics through its portrayal of Ireland's cattle industry, animal slaughter and the cultural currency of meat, arguing that while Joyce diminished the Revival's vegetarianism in 1903, he would later return to the ethical relationship between meat and politics. Historically, animals have tended to be overlooked in ethical accounts of Joyce's writing. Marian Eide's adroit deployment of Levinas in Ethical Joyce (2002), for instance, elucidates the way in which Joyce's writings present the 'ethical obligation to experience and express sympathy' for the other, but, as with Levinas for whom the ethical priority 'is not found in the animal, but the human face', nonhuman others remain unaccounted for in her analysis (Eide 2002, p. 2; Levinas 2003, p. 169). It is only recently that criticism has begun to address the ways in which Joyce's texts often extend beyond the human in their ethical concerns. In David Rando's article on Ulysses and veterinary science, he calls to account the ethics of a "Joyce Industry" that has not attended to nonhuman life but instead reduced animals in Joyce's writings to 'consumable tropes' in a manner comparable to 'slaughterhouses process[ing] animals into food' (Rando 2009, p. 532). A similar concern with Joycean ethics of animal life and death were foregrounded in two articles on vegetarianism in the 2009 'News of Ulysses: Readings and Re-Readings' special issue of Texas Studies in Language and Literature, with Ariela Freedman focusing on nineteenth century influences to Joyce's portrayal of ethical diets and Marguerite M. Regan bringing the novel into dialogue with the vegetarian theory of Carol J. Adams. Rando's proposition that one should read Ulysses as an 'epic of living with animals' (Rando 2009, p. 534) suggests the urgency of a multi-species frame of reading. This mode of reading would recognize Joyce's animals as being imbued with as much (or little) ontological liveliness as their human counterparts, albeit with an alterity that in its unknowability differentiates them absolutely from the novel's human characters. It is an alterity that is perhaps nowhere clearer than in the untranslatable, unreadable 'Mrkgnao!' that substantiates Bloom's sense that cats seem to 'understand what we say better than we understand them' (Joyce 1986, p. 45). The cats, dogs, horse, chickens, cattle, sheep, bats, gulls, rats, flies, worms and other beastly beings that populate the novel not only emphasize the inter-species reality to urban life in early twentieth century Ireland, but, as I shall argue below, enable Joyce to bring into question pressing ideas of nonhuman subjectivity and more-than-human ethical responsibility.

The nascence of a criticism that re-reads Joyce's animals as animals runs parallel with what has been termed the "animal turn" within continental philosophy and literary theory, in which Jacques Derrida's late writings on the ethical questions that accompany acknowledging the 'absolute alterity' 
of the animal other (Derrida 2008, p. 11) and J. M. Coetzee's formally innovative critiques of animal slaughter in the fictions of The Lives of Animals (1999) and Elizabeth Costello (2003) have emerged as central texts. It is a "turn" that registers the ethical implications of the deconstruction of the human as a transcendental subject, in which, as Cary Wolfe writes, the category of the "the human" is revealed to have been 'achieved by escaping or repressing not just its animal origins in nature ... but more generally by transcending the bonds of materiality and embodiment altogether' (Wolfe 2010, p. xv). Not always harmonious with this "animal turn" in philosophy and literature has been the emergence of what Laura Wright outlines as the 'activist, theoretical mode' of feminist vegan studies (Wright 2015, p. 16). A body of cultural criticism that attends to what Carol J. Adams identifies as the 'overt associations between meat eating and virile maleness,' vegan studies implores critics to not only attend to cultural representations of animal bodies but the 'patriarchal attitudes' encoded in such representations (Adams 2010, pp. 25-26). The distinction between vegetarianism and veganism, a word that was only coined in 1944, is for Wright not merely pragmatic (vegans abstain not only from meat but all animal products) but theoretical: veganism further develops vegetarianism's orientations towards questions of animal suffering and slaughter (Wright 2015, pp. 3-6). As Adams writes in her 'Preface to the Tenth Anniversary Edition' of The Sexual Politics of Meat: A Feminist-Vegetarian Critical Theory (1990), if vegetarianism focuses on slaughter and death, veganism examines how 'animals are doubly exploited: both when they are alive and when they are dead' (Adams 2010, p. 21). Vegan studies, in both Wright's and Adams's terms, would extend the consciousness-raising impetus of everyday animal ethics to a critical practice that focuses on animal suffering and commodification. While theorists associated with the "animal turn", such as Donna J. Haraway, have warned that veganism runs the risk of insisting on absolutist moral code that would constitute a restrictive 'Feminist Doxa' (Haraway 2008, p. 80), Wright's work insists on a definition of veganism in which it is understood that there is no 'singular reason' for veganism and no 'singular representative vegan body' but rather a plurality of cultural and dietary motives and practices (Wright 2015, p. 8). Despite points of difference, both critical vegan studies and animal philosophy are predicated on reappraising how embodiment, materiality, and language, structure human and animal relations. Within this critical milieu of theories, ontologies and ethics that examine animals and human society, Joyce's writings present themselves as uncannily contemporary. In its portrayal of vegetarianism and meat production, Ulysses is a text that both historicizes and theorizes animal life and death, inviting itself to be read alongside these later texts and proleptically engaging with the ethical questions foregrounded in contemporary attempts to theorize animal death and consumption.

\section{Vegetable Philosophy and Branded Bodies}

Although, as I will examine below, by the time he was writing Ulysses, Joyce's views on meat and slaughter were more nuanced than his outright rejection of vegetarianism in 1903, there nonetheless remains a sense in which the novel damns the "vegetable philosophy" that he had found so objectionable as a young writer. Lindsey Tucker's study of alimentary symbolism in Ulysses foregrounds the centrality of eating to the subject-forming of Bloom (Tucker 1984, pp. 45-46) and Bloom's self-professed love for 'solid food' speaks to a materialism that explicitly contrasts with the vegetarian Russell's 'ethereal' abstinence (Joyce 1986, pp. 136, 508). While Bloom's capacious materialism is bound up with his atheistic scepticism towards the existence of 'the soul', Russell's theosophical vegetarianism broadly aligns him with religious practices that promise transcendence through dietary restrictions. Indeed, Russell's doctrinal vegetarianism is comparable to Stephen's attempt to cleanse his soul of its 'congealing ... gross grease' through a penitence involving 'all the fasts of the church' in A Portrait of the Artist as a Young Man (1916) insofar as both are structured by absolution and eternity (Joyce 1986, p. 518; Joyce 2000, pp. 94, 127). As Richard Ellmann notes, the 'insipid[ness]' and 'otherworldliness' of Russell's vegetarianism precisely serves as a 'denial of [the] fleshliness' that the reader finds affirmed in Bloom (Ellmann 1982, p. 77). 
Where a parallel does emerge between Bloom and Russell is in their shared preoccupation with reincarnation. Freedman notes that the late-Victorian theosophy that informs Russell's vegetarianism is indebted to the Pythagorean conception of metempsychosis, in which to kill an animal is to risk murdering a transmigrating soul, hence Bloom's inward mocking of the vegetarian superstition that the 'eyes' of dead cattle will 'pursue' meat-eaters 'through all eternity' (Freedman 2009, pp. 449-50; Joyce 1986, p. 136). Yet Bloom is also fascinated with metempsychosis; he recalls the concept several times throughout the novel, beginning with his explanation of the term to Molly with the example that 'the ancient Greeks ... used to believe you could be changed into an animal or tree' (Joyce 1986, p. 53). Unlike Russell, however, for Bloom this continuity between not only life and death but the human and the animal or plant is a material rather than transcendent process. Bloom's observation in Glasnevin cemetery in 'Hades', for instance, that 'flesh' and 'blood' from corpses 'sinking in the earth gives life' is a description closer to an ecological understanding of transformation than Russell's theological notion of the animal soul leaving the body (Joyce 1986, p. 89). Moreover, if spiritual reincarnation structures Russell's vegetable philosophy, Bloom's material understanding of metempsychosis offers a justification for carnivorousness. Just as a human corpse is nothing more than a 'square feed' of '[o]rdinary meat' for the cemetery rats, eating animals is merely part of a material economy of transformative consumption and excretion in which the human plays her or his part by 'stuffing food in one hole and out behind' (Joyce 1986, p. 94,144). Bloom, who is introduced to the reader by way of his relish for 'the inner organs of beasts and fowls' (Joyce 1986, p. 45), embodies the repudiation of a "vegetable philosophy" that would derive dietary restrictions from theological precepts.

Meatless diets, Wright suggests, are always situated at the social margins and have 'never been the dominant ethical and dietary position in any culture at any time' (Wright 2015, p. 6) and certainly Bloom's relish for meat was, and remains, the normative social position. At the turn of the twentieth century, meat did not just constitute a dietary staple for those who could afford it but, with the cattle industry accounting for two-thirds of Ireland's wealth and more than fifty percent of Ireland's entire land surface being used for the raising of livestock, it structured the country's economy and geography (Ross 1987, p. 31). Bloom's background is bound up with this economic history, having previously been employed as a clerk at 'Dublin Cattle market on the North Circular Road' as an employee of Joseph Cuffe, a historical figure who, in addition to his business premises at 5 Smithfield, was a justice of the peace and the owner of "Cuffesboro", an estate near Ballacolla (Joyce 1986, p. 556; Costello 1981, p. 53). Furthermore, as Peter Costello elucidates, the Blooms' previous residency at the City Arms Hotel, a building located immediately behind the pens and stalls of the market, further embeds them within the context of the cattle industry. In addition to offering rooms the City Arms Hotel housed the offices for the Irish Cattle Traders and Stock Owners and was a popular hostelry for droving cattlemen (Costello 1981, p. 53). While it is commonplace to locate Bloom the ad-canvasser within an emergent modern media landscape, less remarked upon is Joyce's intention to situate Bloom's background in Ireland's decidedly nineteenth century agricultural economy.

Bloom's background in the cattle industry carries politicized implications that Joyce was all too aware of. In 'Ireland at the Bar' (1907), Joyce addresses the question of "cattle driving", a successful form of civil disobedience among the Irish labouring classes from 1905 onwards, in which livestock was illegally driven from pastures that might have been used for sustenance farming or growing food crops for the domestic market. Joyce describes the 'violent' measure of cattle driving as a reasonable response to 'seeing the pastures full of well-fed cattle while an eighth of the population is registered as being without sustenance', and is unsurprised that the English press were reporting it as nothing less than an 'agrarian revolt' (Joyce 2008, p. 147). Such agitation, Joyce's essay intimates, is the consequence of a colonial cattle industry that has become hugely overinflated, a fact attested to by the historical figures from the period. In Richard Perren's history of the international meat industry he remarks that in 1893 alone 2.3 million cattle were sent from Ireland to Britain (Perren 2006, p. 53). While Terence Matthews has convincingly argued that the posthumously attributed essay 'Politics and Cattle Disease' is a definite misattribution (Matthews 2007, p. 442), Ulysses is careful to portray the economic 
situation that would produce violent unrest only a year after the novel is set. Mr Deasy's letter on the 'allimportant question' of foot-and-mouth disease, an outbreak of which afflicted Irish livestock in 1912, is not as sometimes read an example of provincial pedantry (Joyce 1986, p. 27). Rather, it conveys the fact that any perceived threat to the cattle industry was also a danger to colonial stability, a view which finds its counterpart in the republican bar talk around 'taking action in the matter' of cattle disease in 'Cyclops' (Joyce 1986, pp. 258-59).

Moreover, it is not only humans who Joyce portrays as having influence in shaping the everyday realities of Ireland's cattle economy. In the 'Hades' episode, Paddy Dignam's funeral cortege is brought to a halt by a 'drove of branded cattle' on a parallel journey to a different underworld:

[They] passed the windows, lowing, slouching by on padded hoofs, whisking their tails slowly on their clotted bony croups. Outside them and through them ran raddled sheep bleating their fear.

-Emigrants, Mr Power said.

Thursday, of course. Tomorrow is killing day. Springers. Cuffe sold them about twentyseven quid each. For Liverpool probably. Roastbeef for old England. They buy up all the juicy ones. And then the fifth quarter lost: all that raw stuff, hide, hair, horns. Comes to a big thing in a year. Dead meat trade. Byproducts of the slaughterhouses for tanneries, soap, margarine. Wonder if that dodge works now getting dicky meat off the train at Clonsilla. (Joyce 1986, pp. 80-81)

Bloom's recollection of working for Cuffe provides the basis for his insight into the economic structure that has enabled Ireland to become a colonial cattle pasture. As Bloom identifies, it is not only the volume of meat being sent to England that denotes Ireland's exploitation but the transporting of live exports, or 'emigrants' as Mr Power describes them, rather than readily slaughtered and butchered cuts of meat. Perren calculates that in the late Victorian period every animal landing at Deptford, London, brought between $£ 5$ to $£ 6$ to the local economy through its 'slaughter, butchering, sale, and processing of byproducts' (Perren 2008, p. 145). Bloom's inner lament that live export means 'the fifth quarter is lost' identifies the market conditions that not only perpetuated Ireland's status as a colonial grazing land but entrenched the social inequality in which, while the English masses get cheap cuts of beef, the working-class Irish must content themselves with dangerous 'dicky meat' on the black-market.

Certainly, Joyce is engaging with colonial politics here. Wim Van Mierlo has shown that in Joyce's early notebooks for the scene Bloom is even more virulent in his stance against live export and offers an explicit 'nationalist criticism' of British economic policy (Van Mierlo 2006, p. 188). Yet, through its formal innovations the passage extends beyond an exclusive focus on human suffering. Joyce's employment of an unstable narrative perspective enables Bloom's economic observations to be read not only as an anti-colonialist commentary but as a simultaneous retreat from the 'fear' that he hears in the cries of the livestock. The seamless movement from a free-indirect third person narration focalized through Bloom ('a divided drove of branded cattle passed the window ... bleating their fear') to interior monologue ('Thursday, of course') evokes both a slippage and disjuncture between the external world and Bloom's inner self. While the free indirect discourse initially establishes the way in which Bloom is unable to not hear the 'fear' in the 'lowing' and 'bleating' livestock, the subsequent interior monologue marks a withdrawal from the outside world into the safety of his own thoughts. Joyce's formal deviation from realism works to evoke Dublin as an inharmonious space of interspecies subjectivities. While Bloom cannot help but feel himself, momentarily, accountable to the animals surrounding the carriage, the shift inwards to calculations on the '[d]ead meat trade' drowns out the noisy, branded bodies who make a claim on him in the external world. It is a moment in which Joyce's prose works to register both the experience of hearing the voice of the animal other and the cognitive strategies through which such voices are displaced.

That Bloom's turn to economic concerns is in part an attempt to displace the unsettling cry of the animal is further implied in the idea which he immediately shares with the other men in the carriage for 
a 'tramline' which would take '[a]ll those animals ... in trucks down to the boats' (Joyce 1986, p. 81). The rail line, which Bloom first contemplates as he walks to the butchers in 'Calypso' (Joyce 1986, p. 47), is not just an expression of impatience in having to share Dublin's roads with livestock drovers, but is indicative of what Chris Otter describes as the late-Victorian development of maximising profits through the streamlining and centralising of animal transportation and slaughter (Otter 2008, p. 96). If for twenty-first century readers the Dublin of Ulysses is notable for its profusion of urban animals, Joyce has Bloom, the would-be agribusiness entrepreneur, embody the emergence of a technologically advanced capitalism that intends to consciously erase livestock from the city. Just as Buck Mulligan later cites the 'revolting spectacle' of 'suspended carcasses of dead animals' on Dublin's streets as indicative of cultural stagnation and provinciality (Joyce 1986, p. 342), Bloom's assertion of the necessity for the modernisation of Ireland's cattle industry portrays a cultural movement towards the making invisible of the animals required in the meat production. Bloom's imagined rail line would literally conceal the 'branded' bodies he has seen and mute the 'fear' he has heard.

\section{Seeing Ourselves as Others See Us}

Elsewhere in the novel Bloom demonstrates an attentiveness towards animal suffering that contrasts with his withdrawal in 'Hades'. From his recollection of bringing home a 'dog (breed unknown) with a lame paw' to the helpless pity he feels for the 'poor brute' horse 'dragging a sweeper' through Dublin's midnight streets and his somewhat self-serving endorsement of the '[p]revention of cruelty to animals' as he tries to prove his own humanity to his accusers in 'Circe', Bloom's empathy for animals is a key trait through which he is characterized (Joyce 1986, pp. 371, 537, 541). How, then, does one account for his active evasion of animal suffering in 'Hades'? Freedman notes that Bloom's eating of pork, which transgresses Jewish Kosher laws, outwardly establishes a secular identity among Dublin's middle classes (Freedman 2009, p. 448) and Bloom's impulse to share his plans for a livestock transportation system can be seen to serve a similar function. It asserts his equivalence with the other men in the funeral carriage moments after John Power's comment on the family 'disgrace' of suicide has invoked the spectre of Bloom's Jewish father, Rudolf Virág (Joyce 1986, p. 79). Bloom's espousals of a modernized agricultural infrastructure are on one level a performance through which he hopes to shore up a masculine Irish identity and distance himself from the shame of his father's Judaism and suicide. The cattle destined for literal slaughter are also figuratively ground up in the production of Bloom's own masculinity. Bloom himself is not unaware of the way in which meat can provide sustenance for one's identity as well as one's physical body. Recalling the slogan 'Roastbeef for old England' (Joyce 1986, p. 81) as he looks out at the cattle, Bloom not only identifies what Harriet Ritvo describes as beef's status as a symbol of patriarchal and colonial superiority within the mythology of British Imperialism, but, moreover, he recognizes Ireland's unwitting complicity in the process as it literally sustains the colonial center with an unremitting flow of hoofed 'emigrants' (Ritvo 2005, p. 305; Joyce 1986, p. 81).

Over the course of Ulysses, Joyce demonstrates the ways in which both the symbolism and the materiality of meat is co-opted within patriarchal political structures, in which the co-constitutive relationship between slaughter and constructions of patriarchal sovereignty functions across otherwise stark ideological differences. In both the description of an Irish agriculture restored to a prelapsarian state of 'herds innumerable' whose 'udders [are] distended with superabundance' that interpolates the citizen's nationalist bar talk and Mr Deasy's aforementioned pronouncements on protecting '[o]ur cattle trade' there is a recognisable correlation between meat, masculinity and politics that cuts across Unionist and Republican divisions (Joyce 1986, pp. 27, 242). In both instances, animal bodies are figured as currency within a mode of patriarchal sovereignty. In structuring even oppositional political positions the novel illuminates what Derrida describes as 'carnophallogocentrism', a neologism that conveys the 'carnivorous virility' inherent to Western society, in which '[a]uthority and autonomy' are attributed to 'the man ... rather than to the woman, and to the woman rather than to the animal' (Derrida 1995, pp. 280-81). The carnivorous virility that Derrida outlines is not a feature of society or 
certain ideologies, rather it structures society: it is the sacrificial 'schema of the dominant' ingrained in the Western idea of sovereignty itself (Derrida 1995, p. 281). Since sovereignty and carnivorousness cannot be absolutely separated, Derrida explains, even those who identify as vegetarian, and it should be added, vegan, are unable to escape this sacrificial structure but instead 'practice a different mode of denegation' (Derrida 1995, p. 282). Joyce also implicates the politics of vegetarianism as guilty of that which it purports to oppose. In 'Telemachus', Stephen satirizes the way in which revivalists such as Yeats and Russell are just as complicit with the appropriation of animal bodies as their political counterparts. What Stephen observes as their misrecognition of an authentic Irishness in the image of the milkmaid 'crone' wandering among the '[s]ilk of the kine' and '[c]rouching by a patient cow at daybreak in the lushfield' obfuscates the grim reality of Dublin's dairy industry for both humans and cattle laborers, whose working conditions in the 'filthy cowyard at Stradbrook with its foul green puddles and clots of liquid dung' sickened him in Portrait (Joyce 1986, p. 12; Joyce 2000, p. 53). Stephen ironizes the ways in which the organic nationalism of the Revival appropriates and, symbolically if not literally, consumes animal bodies. The cultural revivalists, in much the same manner as the Unionists, Republicans and colonists, are shown to practice a politics of meat. To overturn carnophallogocentrism, Joyce makes clear, would involve deconstructing the dominant mode of patriarchal sovereignty itself; an idea bluntly reiterated in Molly's appraisal that 'itd be much better for the world to be governed by the women in it you wouldnt see women going and killing one another and slaughtering' (Joyce 1986, p. 640, my emphasis). While Molly is here alluding to human slaughter in the context of military and colonial violence (and reflecting the novel's composition during the Easter Rising and World War I), her sentiment and language reinforces the novel's portrayal of a sacrificial schema that crosses species boundaries. As in the mock Parliamentary interlude in 'Cyclops', where a thinly disguised Arthur James Balfour, the then British Prime Minister, is asked whether 'similar orders' have 'been issued for the slaughter of human animals who dare to play Irish games in the Phoenix park' as those issued for diseased cattle, Joyce presents a continuity between human and animal killing within the dominant political order (Joyce 1986, p. 259).

Bloom identifies his own complicity within this mode of carnivorous masculinity in 'Lestrygonians', the episode which Joyce intended to follow the 'rhythm ... of the digestive organs' and which, unsurprisingly, provides the novel's most sustained engagement with the question of killing and eating animals (Budgen 1972, p. 100). Following his unfavourable encounter with the vegetarian Russell, Bloom enters the Burton restaurant where he undergoes a sudden sensory assault:

Stink gripped his breath: pungent meatjuice, slop of greens. See the animals feed.

Men, men, men.

Perched on stools by the bar, hats shoved back [ ... ] wolfing gobfuls of sloppy food, their eyes bulging, wiping wetted moustaches. [ . . ] A man spitting back on his plate: halfmasticated gristle [ . . ] See ourselves as others see us. (Joyce 1986, pp. 138-39, my emphasis)

Bloom's Anglicized recollection of the final stanza of Robert Burns's 'To A Louse' (1786), with its wish to be able to see one's self from a socially defamiliarizing outside perspective, is a continuation of his earlier interest in imagining the world through different eyes. Just as in 'Calypso' he has imagined himself as seen by his cat ('Wonder what I look like to her. Height of a tower? No, she can jump me.' (Joyce 1986, p. 45)), Bloom is here preoccupied with the implications of what it means to be seen from a position of radical alterity, and the sense of exposure and accountability such a gaze can provoke. It is also a meta-textual joke since the reader is precisely the 'other' whom Bloom imagines watching him: after-all, the first time the reader "sees" Bloom is in the aforementioned context of eating 'inner organs' with relish (Joyce 1986, p. 45). Bloom's reluctant self-identification with the brutish eaters of the Burton, whose beastly voraciousness parallels the man-eating Laestrygonians in Homer's Odyssey, serves to implicate him within an exaggerated, grotesque version of what Derrida describes as the carnivorous 'virile strength of the adult male' (Derrida 1995, p. 281). Throughout 
Ulysses Bloom's masculinity and sexual identity is shown to be bound up with questions of eating and meat. In 'Cyclops', the narrator insinuates Bloom's effeminacy in the significance attached to the fact that he would go without 'meat of a Friday' in order to appease the devout Mrs Riordan (Joyce 1986, p. 251). In contrast, in 'Calypso' Bloom asserts an incestuous virulence as he 'prod[s] a fork into the kidney' and thinks of the 'sex breaking out' in his '[p]ert little piece' of his daughter Milly (Joyce 1986, p. 51), in which, as Joseph Valente has pointed out, a pun on kiddy and 'kidney' creates an incestuous subtext of anthropophagy (Valente 1997, p. 24). In 'Circe', however, it is the prospect of Bloom himself being 'slaughtered and skewered' that denotes the zenith of his emasculation by Bello Cohen (Joyce 1986, p. 434). Even Bloom's cuckolding is denoted through the symbolism and materiality of meat. Returning to his marital bed, it is not dried semen but 'flakes of potted meat' between the bed sheets that comically signify Blaze Boylan's erstwhile presence (Joyce 1986, p. 603). Bloom's sexual identity is repeatedly constructed or deconstructed in relation to the dominant logic of carnophallogocentric masculinity.

Leaving the Burton restaurant, the 'wings of his nose' 'tightening' in repugnance, Bloom wishes to disassociate himself not only from the 'dirty eaters' but the brutish application of Darwinism that he observes in the mantra of '[e]very fellow for his own, tooth and nail ... Eat or be eaten' (Joyce 1986, p. 139). His rejection of a distorted Darwinian individualism, which colours both inter- and intra-species relationality, provides the catalyst for Bloom to return to the question of human-animal relations and vegetarianism. Turning back towards Grafton street, Bloom reconsiders the aesthetical and the ethical benefits of vegetarianism, contemplating both the 'fine flavour of things from the earth' and the mitigation of unnecessary '[p]ain to the animal' (Joyce 1986, pp. 139-40). In turn, this thought of animal suffering leads Bloom to recall the conditions of the slaughterhouses attached to Dublin Cattle Market:

Wretched brutes there at the cattlemarket waiting for the poleaxe to split their skulls open. Moo. Poor trembling calves. Meh. Staggering bob. Bubble and squeak. Butchers' buckets wobble lights. [ ... ] Rawhead and bloody bones. Flayed glasseyed sheep hung from their haunches, sheepsnout bloody-papered snivelling nosejam on saw dust. (Joyce 1986, p. 140)

Having earlier lambasted Russell's fear of dead cattle pursuing him through eternity, Bloom is now himself haunted by the spectral faces of animals whose killing he has been complicit with. Moreover, the slaughterhouse scene seemingly arrives as a vegetarian intervention not only within Bloom's conscience, but within the novel itself. As Freedman notes, Joyce employs violent and emotive imagery reminiscent of propogandist content in a 'vegetarian tract' (Freedman 2009, p. 457) and the skull splitting poleaxe is suggestive of the humanitarian outcry over slaughterhouse conditions which had led to a 1904 report by the British Admiralty on slaughter methods that advocated phasing out poleaxes (Burt 2006, pp. 126-27). Even Stuart Gilbert's 1930 study of the novel, written with Joyce's guidance, suggests a moral efficacy to the passage, observing that the 'realism of such passages may seem repulsive to some of the omnivores who read them' (Gilbert 1958, p. 204). In the episode to which Joyce assigned the symbol of "bloody sacrifice" in the schema that he sent to Carlo Linati, the slaughterhouse scene arrives as a moment of discomfort not just for Bloom but the reader.

Yet, it is not only his visualisation of the slaughterhouse scene that disturbs Bloom. As in his encounter with the bleating and lowing livestock in 'Hades' and the inhuman speech of his cat in 'Calypso', it is the cry of the animal that holds him to account to the otherness of the animal. The 'moo' and 'meh' that punctuates the imagery of the animals destined for the poleaxe is a call that insists on a space of trans-species intersubjectivity. If earlier in 'Hades', Bloom succeeded in retreating inwards from the frightened cries of the livestock and envisioning an urban infrastructure that would silence them permanently, the ghostly cries have now transgressed into the safety of Bloom's interiority. Moreover, it is the fearful voices of the trembling 'calves' and 'bob' (calves newly born by pregnant cows sent to slaughter) that makes apparent the apprehensiveness in their 'waiting for the poleaxe' and insists not only on the fact of animal selfhood but an ontological relation to their own death (Joyce 1986, p. 140, my emphasis). The slaughterhouse unsettles what Derrida describes as an engrained anthropocentrism 
in modern Western thought, stretching from Descartes to Heidegger, which insists on mortality as an exceptional and defining quality of the human (Derrida 2009, pp. 56-57). If philosophical justifications for the slaughter of animals have relied on a Cartesian understanding of the animal as machine or the Heideggerian notion of the animal as "poor in world", both of which exemplify the animal's lack of full subjectivity in its lack of relation to death, Bloom's slaughterhouse animals insist not on lack but a non-traversable difference that upsets ontological sureties and ethical responsibilities.

In his posthumously published seminar on animal death and mourning Derrida turns to Ulysses, citing the moment where Bloom, standing at the graveside in 'Hades', acknowledges that the notion that '[o]nly man buries' is a fallacy since 'ants too' bury their dead (Joyce 1986, p. 90). Derrida, however, misquotes Bloom's '[n]o, ants too' bury their dead as 'no ants do' and, so, concludes that Joyce 'thinks like everyone else that beasts do not die in the proper sense' (Derrida 2011, pp. 16-17). Derrida's misreading of Bloom, however, only serves to emphasize that Joyce does not think like "everyone else" in this regard. As in his thoughts on ants in 'Hades', Bloom's encounter with the slaughterhouse livestock is marked by a recognition of nonhuman alterity that opens, rather than circumscribes, questions of mortality. If elsewhere in the novel Joyce portrays the expansion of a carnophallogocentric schema that cuts across nationalist and colonialist lines, an expansion analogous with the modernisation of meat production, Bloom's slaughterhouse nightmare suggests that the "human", defined in terms of an ontological relation to death, is vulnerable to the intrusive agency of the animal alterity it would look to deny.

\section{Bloom's Sympathetic Imagination}

Joyce presents Bloom's vision of the slaughterhouse in terms that clearly stress empathy for animals whose lives have been marked for slaughter. While it is not clear if Bloom is thinking of those animals whose deaths he remembers or whose deaths are conceivably taking place at the Cattle Market in the very moment he imagines them, either way, the fact that the animals are imagined rather than real does not diminish the ethical purchase of the experience for Bloom. Indeed, in a certain respect the imaginative aspect heightens his sense of being held to account, portraying what J. M. Coetzee suggests is the centrality of the "sympathetic imagination" in any ethical encounter between humans and animals. Coetzee introduced the concept of the "sympathetic imagination" in his 1997 Princeton Tanner lectures, two lectures delivered as metafictional narratives in which a fictional writer named Elizabeth Costello gives a public lecture and a seminar on the subject of vegetarianism and animal ethics, in which the 'sympathetic imagination' is situated as the faculty through which 'we can think ourselves' into other beings (Coetzee 2004, p. 80).

The lectures were subsequently published as The Lives of Animals (1999) and then reprinted, with minor changes, alongside six other Costello narratives in Elizabeth Costello: Eight Lessons (2003). Despite having been marketed as a novel by its publishers, Elizabeth Costello is a work that resists being firmly placed in any single category, instead inhabiting the border space between novel, fable, essay and, as suggested by its subtitle, lessons or lectures. Moreover, it is a work that explicitly writes back to Joyce. As a writer, Costello is famed for having written a sequel to Ulysses that 'take[s] Molly out of the house', an act of Joycean appropriation that is bound up with her animal ethics since it is the 'sympathetic imagination,' Costello states, that enables her to both 'think [her] way into the existence' of a fictional character such as Molly Bloom and to 'think [her] way into the existence of a bat or a chimpanzee or an oyster' (Coetzee 2004, pp. 13, 80). More recently Coetzee has further nuanced this link between fiction and ethics. An act of 'sympathetic identification,' Coetzee explains, slightly modifying the term, 'allows us to enter other lives and to live them from the outside'; the same mode of imaginative identification that operates 'when we read novels' is at work when we imagine the interiority of 'other forms of life' (Coetzee and Kurtz 2015, pp. 133-34). In one's intersubjective encounter with fictional characters there is a structural similarity to one's encounter with animals insofar as both rely on the imagination yielding what Coetzee calls 'fictional truths' (Coetzee and Kurtz 2015, p. 134). The link between fictionality and animal alterity is similarly foregrounded in 
Joyce's portrayal of Bloom's sympathetic encounter with the slaughterhouse livestock. As in Coetzee's description of the way in which the imagination both enables and circumscribes our capacity to access the lives of others, the sheep and calves of the slaughterhouse embody both the possibilities and limits to Bloom's identification with the livestock. The 'glasseyed' dead stare of the 'sheep hung from their haunches' direct a penetrating gaze of absolute otherness onto Bloom, insisting on a spectral ontology, yet the glassy surface of their eyes is a figure for the way in which Bloom is reflected back upon himself as he looks at the animal. His recognition of animal alterity is accompanied by the impossibility of his access to nonhuman interiority. Here, the exercise of 'see[ing] ourselves as others see us' takes on a different significance: one literally sees one's own self in the eyes of the other (Joyce 1986, p. 138).

The centrality of the imagination and sympathy to Bloom's encounter is further foregrounded in the passage immediately following the description of slaughterhouse in which Bloom imagines '[f]amished ghosts' licking up the '[h]ot fresh blood they prescribe for decline' (Joyce 1986, p. 140). As Don Gifford notes, this is an allusion to the eleventh book of Homer's Odyssey where Odysseus, having voyaged to the underworld, sacrifices the blood of his best ram and is crowded by ghosts famished for the taste of blood (Gifford 1988, p. 179). It is further confirmation that Bloom's slaughterhouse scene should be read as invoking the blood sacrifice that Joyce detailed in his schema. Moreover, it presents an additional parallel with Coetzee's Elizabeth Costello. In the novel's final lesson Costello, like Bloom, connects the violence enacted on animals with the 'pallid dead ... slavering for a taste' of Odysseus's slaughtered ram (Coetzee 2004, p. 211). As with the individuated livestock who haunt Bloom's mind, there is an ontological singularity to Costello's imagining of Odysseus's ram. She 'believes, most unquestionably in the ram'; for her '[t]he ram is not just an idea, the ram is alive though right now it is dying' (Coetzee 2004, p. 211, my emphasis). In an example of where the novel problematizes the notion that Costello is an unmediated conduit for her author, the novel goes onto to demonstrate the impossibility of such a clean break between the embodied animal (its being 'alive') and the imagined animal (its being 'jut an idea'). In the final lesson, while trying to describe the frogs of her 'childhood in rural Victoria' Costello is forced to acknowledge that her description cannot get to the true essence of the specific frogs of her youth, that they remains 'lamentably literary', trapped in the structures of the 'allegorical' (Coetzee 2004, pp. 217-20). Costello's complaint echoes Derrida's insistence in 'The Animal That Therefore I Am' that the cat he is describing is his own, singular pet cat not the cats of La Fontaine, Ludwig Tieck or Lewis Carroll, a gesture that intentionally acknowledges the impossibility of invoking his individual cat without the contamination of all these other intertextual traces (Derrida 2008, p. 9). The intermediary force of language, Derrida implies, opens the singularity of the animal to textuality and intertextuality. It is also what prevents Costello's attempt to describe the exact, unsubstitutable frogs of her childhood. In much the same way as her childhood frogs, Coetzee shows that she cannot describe the singular, embodied ram in Homer's Hades without simultaneously invoking the 'idea' of the ram with its profusion of mythological and cultural traces. Costello's notion of the 'sympathetic imagination' is shown, despite her assertions otherwise, to be marked by both an ontological singularity and a textuality that opens it to the impersonality of discourse.

This muddying of singularity, textuality, and intertextuality similarly structures Bloom's thoughts on animal alterity. While Gilbert remarks upon the 'realism' of the slaughterhouse imagery, it is rather Joyce's modernist departure from novelistic conventions through the foregrounding of textuality that characterizes his presentation of Bloom's trans-species encounter. Like Costello, Bloom might wish to attend to the absolute singularity of the slaughterhouse animals, that is, their realism, but his imagining of them is shot through with cultural associations, tropes, and artifice. From the imagery of '[r]awhead and bloody bones' (Joyce 1986, p. 140), which Gifford lists as figures from 'Irish folklore' (Gifford 1988, p. 179) to the aforementioned Homeric parallel, Bloom's sympathetic imagining is a tissue of cultural traces. Indeed, it is the irreducible profusion of cultural associations that complicates any seemingly straightforward ethical imperative to Bloom's slaughterhouse vision. The 'famished ghosts' who have been 'proscribe[d] blood for decline' (Joyce 1986, p. 140) have a polysemantic agency, since they not only invoke the inhabitants of Homer's underworld, but, as Luke Gibbons notes, they also allude 
to the victims of Ireland's nineteenth century famines and the difficulties of alimentary sustenance under colonial rule (Gibbons 2015, pp. 189-90). It was during the Great Famine of 1845-1852 that English speculators purchased vast swathes of Irish arable land with the intent to convert them to cattle pastures, and Joyce appears all too aware that the human ghosts of the famine and the spectral animals of the slaughterhouse share a history (Ross 1987, p. 31). The blood drinking ghosts of Ireland's human population, arriving on the heels of the Cattle Market's slaughtered animals, present an image in which the eating of animals is not linked to a position of inherent carnivorous power but, rather, 'decline' (Joyce 1986, p. 140). If the Burton diners perform the meat-eating masculinity through which carnophallogocentrism is made visible, the ephemeral famished ghosts offer a more complex image of this sacrificial structure, in which one's identity cannot be reduced to binaries of eater or eaten, human or animal. The category of vegetarian and non-vegetarian is unable to accommodate those who have already been denigrated as less than human. With the medicinal drinking of blood offering an echo of Bloom's earlier musings that the live export of animals means that the off-cuts and secondary products that might be of benefit to the lower classes are lost, the slaughterhouse vision concludes by eschewing the simplistic reappraisal of vegetarianism that prompted Bloom's imagination in the first place.

A further undermining of Bloom's ethical resolve takes place moments later as he sits down to a pointedly meat-free cheese sandwich in Davy Byrne's '[m]oral pub' (Joyce 1986, p. 140). Occasionally referred to as the text's "vegetarian moment", it has tempted critics to apply a moral narrative to the chapter. In Richard Ellmann's grand phrasing, 'forced to make an existential choice' between the 'fleshless' vegetarianism of Russell and the bloody 'flesh' of the Burton, Bloom finds a middle way by ordering a meal 'formed from mammal's milk without slaughter' (Ellmann 1982, p. 78). Regan similarly finds an ethics to celebrate here too, declaring the episode to resound with 'proto-vegetarian stirrings' (Regan 2009, p. 466), while Tucker celebrates Bloom's eating of dairy, on the basis that milk is a 'primary liquid' that promises 'regeneration' rather than death (Tucker 1984, p. 71). Yet, to see Bloom's meal at Davy Byrne's as a moment of triumphant vegetarianism is to skewer the text to an ideology that Joyce's ironic modernist form actively resists. As in Bloom's slaughterhouse vision, where his imagination produces a profusion of cultural and historical associations that qualify questions of responsibility, Joyce's interior monologue enables the novel's form to complicate Bloom's actions. Sitting at the bar, Bloom's mind follows an associative trajectory: 'Christmas turkeys and geese. Slaughter of innocents. Eat drink and be merry. Then casual wards full after. Heads bandaged. Cheese digests all but itself. Mity cheese-Have you a cheese sandwich?' (Joyce 1986, p. 141). While Bloom's quip on Herod's infanticide, positioning the birds who are killed every Christmas as the slaughtered innocents, correlates with his previous horror at animal sacrifice and the desire for a meatless lunch, his apparently involuntary recollection of cheese digesting 'all but itself' is, as Gifford notes, an anachronistic aphorism that refers to the use of rennet, 'a substance derived from [the] stomachs' of ruminant mammals, predominantly calves, in cheese production (Gifford 1988, p. 180). If moments earlier Bloom has imagined 'calves' and 'bob' 'staggering' in the blood of the slaughterhouse (Joyce 1986, p. 140), here he implicitly acknowledges veal slaughter as an integral component of dairy production. Cheese, the '[c]orpse of milk' as Bloom calls it elsewhere, is as tainted as meat and has the same potential to be appropriated within a virulent carnivorous masculinity, as Joyce will show in 'Oxen of the Sun', when Buck Mulligan issues the misogynistic imperative that every man should 'drink, an udderful!' and not just from cows but 'Mother's milk, the milk of human kin' (Joyce 1986, pp. 94, 346).

That Bloom orders his sandwich after these thoughts have occurred to him suggests not a moment of vegetarian transcendence but rather a tacit acceptance of his inability to break with the economy of sacrifice and death that he has identified. Even the mites who colonize the dairy product, providing Bloom the canvasser with a witty pun, worry the distinction between killing and not-killing, life and death, that, like those vegetarians he encountered earlier, he would rather transcend. Understood as a desire to make a moral calculation when it comes to eating, Bloom's cheese sandwich is a failure; it is undone by language's ever deferring movement towards allusions, intertexts and histories 
that undermine the properness of the action. Bloom's cheese sandwich is unable to live up to a vegetarianism that promises that the ghostly eyes of dead animals will avert their gaze. While Bloom's sympathetic imagination opens him to the alterity of animals, their relation to death and difficult questions of ethical responsibility, the imagination's simultaneous movement towards a proliferation of cultural, textual and historical traces contaminates any pragmatic moral conclusion that might be reached. In Bloom's cheese sandwich Joyce challenges, rather than endorses, an ethics that would stake its claim on absolution through abstinence.

\section{Conclusions}

In 'Ithaca', musing on whether 'human life was infinitely perfectible', Bloom reminds himself that the 'integral parts of the human whole' are reliant on 'the necessity of destruction to procure alimentary sustenance' (Joyce 1986, p. 572). To eat, Bloom understands, is to take from the outside and to subsume it within the self. Sacrifice is what structures 'the painful character of ... separate existence' (Joyce 1986, p. 572). This, for Derrida, is why the ethical question is not whether one should abstain from eating others, since 'one must eat' and one 'never eats entirely on one's own'. Rather, Derrida explains, it is a question of 'eating well' (Derrida 1995, p. 282). What constitutes Derrida's notion of 'eating well' is intentionally unspecified; an ethical decision worthy of its name cannot be calculated in advance. In Bloom's failed vegetarianism, Joyce presents us with a portrayal of an attempt to 'eat well' that would seem to insist on the weakness of such an ethics to the point of being ineffective. Yet, while Bloom's sandwich fails as a heroic moral gesture, it nonetheless figures as an event that in its attending to, rather than neglecting, the entangled materialities of animal and human histories finds some ethical purchase. In Bloom's tacit acknowledgement of the suffering and sacrifice that constitutes his lunch, including the veal calves whose spectral presence haunts him much like they do the vegetarian Russell, Bloom moves towards what Haraway describes as accepting one's responsibility in the 'necessity and labor of killing' (Haraway 2008, p. 80). For Haraway, the potential for reconceptualising animal ethics can only be found through recognizing that within a 'relentless historical, nontelological, multispecies, contingency' of cohabitation, killing cannot be avoided (Haraway 2008, p. 80). Earlier in the novel, having rejected the Old Testament species hierarchy in which the angel of death kills the butcher and he kills the ox and the dog kills the cat' as 'a bit silly', Bloom nonetheless comes to a similar conclusion to Haraway: 'justice' always begins by attending to the fact that 'everybody is eating everyone else. That's what life is after all' (Joyce 1986, p. 101).

Yet, if in 'Hades' Bloom's graveside vision of life as incessant consumption and excretion offered a harmonious ecological materialism that flattened species difference, the slaughterhouse of Dublin's Cattle Market forces him to acknowledge the differentiated realities of suffering, terror and pain, to both animals and humans, that constitutes the political and social realities of Ireland (Joyce 1986, pp. 101, 140). The nightmare of history, Joyce shows, is structured by a schema of sacrifice in which women, the poor, and animals are seen as dispensable. That is not to say, however, that they are presented as inhabiting the same social position. While Molly might be slapped on the hind like 'a horse' by Boylan and milked like a 'cow' by Bloom, she nonetheless has an agency and freedom that far exceeds Joyce's portrayal of actual cattle and horses (Joyce 1986, pp. 610, 621). In contrast to the animals in the novel, Molly is afforded a 'human, all too human' voice that can serve as an 'indispensable countersign' to those who would objectify her within a carnophallogocentric schema (Joyce 1957, pp. 159-60). Yet, it is the illegibility of the animal voices rendered on the pages of the novel-the cries of cattle, sheep, cats and other creatures - that insists not only on their absolute alterity, but the impossibility of their being too readily ignored or discounted. Joyce attends to the historical conditions of Ireland's animals and their role as actors in a more-than-human history, but does so in such a way that resists reducing them to anthropomorphic figures all too easily read and consumed. Instead, like the horror of seeing one's own self reflected in the glassy eyes of a sheep hung from it haunches, Joyce's animals remain in a certain sense unreadable, reflecting our own image back upon ourselves. In this regard Ulysses itself offers a performative model for "eating well". Terry Eagleton 
has argued that the difficulty of Joyce's novel works to induce a literary 'dyspepsia' in the reader that prevents her or him from easily consuming and digesting it (Eagleton 1998, p. 206). If Ulysses does cause indigestion in the reader in the manner that Eagleton suggests, it is of an ethically productive kind. It draws attention to and thereby forestalls the forces of appropriation through which one consumes otherness, digesting it until there is no distinction between self and other. The dyspepsia of Ulysses is akin to the 'nourishing indigestion' that Haraway suggests is required 'for eating well together' (Haraway 2008, p. 300, my emphasis). Joyce's insistence on both historicising and theorising the production of meat through modernist innovations produces an ethics of reading in which the reader, unable to know in advance how to respond to the text, remains cognisant of the processes of consumption taking place.

Eugene Jolas recounts that during the 1930s Joyce would 'usually lunc[h] at a vegetarian restaurant [in Zurich] where vegetables were served camouflaged as meat dishes' (Jolas 1998, p. 16). It is an anecdote that suggests Joyce's views towards vegetarianism softened as he grew older. But more than that, there is an insinuation that it was not so much the food that drew Joyce to the restaurant as the presentation of the food. In the vegetables made to look like meat there is an irony that would have been to Joyce's tastes: a vegetarianism that took the guise of the slaughtered bodies it purported to absolve itself of. As Bloom discovers in Ulysses, vegetarianism, if understood as freedom from an economy of sacrifice and the ghosts who haunt it, offers only false transcendence. Ethics, Joyce shows, cannot be reduced to an absolute refusal of sacrifice. Instead, what emerges as central to Joyce's animal ethics is the role of the imagination. Bloom's sympathetic imagination opens him to the inner lives of animals, the responsibility those lives demand of him and the possibility of establishing an ethical relationship across species boundaries. Wright suggests that since veganism's parameters extend beyond vegetarianism's focus on meat, encompassing broader questions of how to coexist ethically with animals, veganism intensifies the paradox that 'one cannot live without causing death' and implicates vegans as 'perhaps the most paradoxical consumers of all' (Wright 2015, pp. 5-6). In his portrayal of Bloom's attempt to "eat well", both impelled by and forged by his response to animals as absolute others, Joyce foreshadows the theoretical aporia of an ethics that must be willing to endure the possibility (and perhaps even inevitability) of failure. In Bloom's inability to extract himself from either the biological conditions which make sacrifice unavoidable or the social conditions which position him as complicit with slaughter, Joyce presents a protagonist whose ethical relationship with animals is circumscribed by the necessities of embodiment and historical contingency. Yet, while Bloom has clearly not converted to vegetarianism by the end of the novel (let alone a practice that resembles veganism), his sense of responsibility towards animals remains unresolved and the carnivorous relish with which he has been introduced to the reader has undergone clear qualification. In his portrayal of animal life and death, Joyce resists either simplifying or sanitizing the ceaseless killing that structures modern society. Instead, Ulysses shows that attending to ethical demands across species differences always involves giving a singular response from a situated position and remaining perpetually open to the responsibilities of living with others.

Conflicts of Interest: The author declares no conflict of interest.

\section{References}

Adams, Carol J. 2010. The Sexual Politics of Meat: A Feminist-Vegetarian Critical Theory. New York: Continuum.

Budgen, Frank. 1972. James Joyce and the Making of 'Ulysses' and Other Writings. Oxford: Oxford University Press.

Burt, Jonathan. 2006. Conflicts around Slaughter in Modernity. In Killing Animals. Edited by The Animal Studies Group. Urbana: University of Illinois Press, pp. 120-44.

Coetzee, J. M. 2004. Elizabeth Costello. New York: Penguin Books, First published in 2003.

Coetzee, J. M., and Arabella Kurtz. 2015. The Good Story: Exchanges on Truth, Fiction and Psychotherapy. London: Harvill Secker.

Costello, Peter. 1981. Leopold Bloom: A Biography. Dublin: Gill and Macmillan. 
Derrida, Jacques. 1995. Eating Well, Or the Calculation of the Subject. In Points: Interviews, 1974-1994. Translated by Peter Connor, and Avital Ronell. Edited by Elizabeth Weber. Stanford: Stanford University Press, pp. 255-87.

Derrida, Jacques. 2008. The Animal That Therefore I Am. Translated by David Wills. Edited by Marie-Louise Mallet. New York: Fordham University Press.

Derrida, Jacques. 2009. The Beast and the Sovereign: Volume I. Translated by Geoffrey Bennington. Edited by Michel Lisse, Marie-Louise Mallet and Ginette Michaud. Chicago: University of Chicago Press.

Derrida, Jacques. 2011. The Beast and the Sovereign: Volume II. Translated by Geoffrey Bennington. Edited by Michel Lisse, Marie-Louise Mallet and Ginette Michaud. Chicago: University of Chicago Press.

Eagleton, Terry. 1998. Edible écriture. In Consuming Passions: Food in the Age of Anxiety. Edited by Sian Griffiths and Jennifer Wallace. Manchester: Mandolin Press, pp. 203-08.

Eide, Marian. 2002. Ethical Joyce. Cambridge: Cambridge University Press.

Ellmann, Richard. 1982. Ulysses on the Liffey. Oxford: Oxford University Press.

Ellmann, Richard. 1983. James Joyce. New and revised edition; Oxford: Oxford University Press.

Freedman, Ariela. 2009. "Don't Eat a Beefsteak": Joyce and the Pythagoreans. Texas Studies in Literature and Language 51: 447-62. [CrossRef]

Gibbons, Luke. 2015. Joyce's Ghosts: Ireland, Modernism, and Memory. Chicago: University of Chicago Press.

Gifford, Don. 1988. Ulysses Annotated: Notes for James Joyce's Ulysses. Revised and Expanded Edition; Berkley: University of California Press.

Gilbert, Stuart. 1958. James Joyce's Ulysses. New York: Vintage Books, First published in 1930.

Gregory, James. 2007. Of Victorians and Vegetarians: The Vegetarian Movement in Nineteenth-Century Britain. London: Tauris Academic Studies.

Haraway, Donna J. 2008. When Species Meet. Minneapolis: University of Minnesota Press.

Jolas, Eugene. 1998. Remembering James Joyce. Modernism/Modernity 5: 2-29. [CrossRef]

Joyce, James. 2000. A Portrait of the Artist as a Young Man. Edited by Jeri Johnson. Oxford: Oxford University Press, First published in 1916.

Joyce, James. 1986. Ulysses: The Corrected Text. Edited by Hans Walter Gabler, Wolfhard Steppe and Claus Melchior. London: Penguin Books, First published in 1922.

Joyce, James. 1957. The Letters of James Joyce Volume. Edited by Stuart Gilbert. New York: Viking Press.

Joyce, James. 1966. The Letters of James Joyce Volume II. Edited by Richard Ellmann. London: Faber.

Joyce, James. 2008. Occasional, Critical and Political Writing. Edited by Kevin Barry. Oxford: Oxford University Press. Levinas, Emmanuel. 2003. The Paradox of Morality: An Interview with Emmanuel Levinas. In The Provocation of Levinas: Rethinking the Other. Translated by Andrew Benjamin, and Tamara Wright. Edited by Robert Bernasconi and David Wood. London: Routledge, pp. 168-80.

Matthews, Terence. 2007. An Emendation to the Joycean Canon: The Last Hurrah for 'Politics and Cattle Disease'. James Joyce Quarterly 44: 441-53. [CrossRef]

Otter, Chris. 2008. Civilizing Slaughter: The Development of the British Public Abattoir, 1850-1910. In Meat, Modernity and the Rise of the Slaughterhouse. Edited by Paula Young Lee. Durham: University of New Hampshire Press, pp. 89-106.

Perren, Richard. 2006. Taste, Trade and Technology: The Development of the International Meat Industry Since 1840. Farnham: Ashgate.

Perren, Richard. 2008. Filth and Profit, Disease and Health: Public and Private Impediments to Slaughterhouse Reform in Victorian Britain. In Meat, Modernity and the Rise of the Slaughterhouse. Edited by Paula Young Lee. Lebanon: University of New Hampshire Press, pp. 127-51.

Rando, David. 2009. The Cat's Meow: Ulysses, Animals and the Veterinary Gaze. James Joyce Quarterly 46: 529-43. [CrossRef]

Regan, Marguerite M. 2009. "Weggebobbles and Fruit": Bloom's Vegetarian Impulses. Texas Studies in Literature and Language 51: 463-75. [CrossRef]

Ritvo, Harriet. 2005. Mad Cow Mysteries. In The Cultural Politics of Food and Eating: A Reader. Edited by James L. Watson and Melissa L. Caldwell. Oxford: Blackwell Publish, pp. 299-306.

Ross, Eric B. 1987. An Overview of Trends in Dietary Variation from Hunter Gatherer to Modern Capitalist Societies. In Food and Evolution: Toward A Theory of Human Food Habits. Edited by Marvin Harris and Eric B. Ross. Philadelphia: Temple University Press, pp. 7-56. 
The Irish Times. 1891. A Vegetarian Restaurant in Dublin. The Irish Times, March 14, 7.

Tucker, Lindsey. 1984. Stephen and Bloom at Life's Feast: Alimentary Symbolism and the Creative Process in James Joyce's "Ulysses". Columbus: Ohio State University Press.

Valente, Joseph. 1997. A Child Is Being Eaten: Mourning, Transvestism and the Incorporation of the Daughter in Ulysses. James Joyce Quarterly 34: 21-64.

Van Mierlo, Wim. 2006. The Greater Ireland beyond the Sea: James Joyce, Exile and Irish Immigration. In Joyce, Ireland, Britain. Edited by Andrew Gibson and Len Platt. Gainesville: University Press of Florida, pp. $178-97$. Wolfe, Cary. 2010. What Is Posthumanism? Minneapolis: University of Minnesota Press.

Wright, Laura. 2015. The Vegan Studies Project: Food, Animals and Gender in the Age of Terror. Athens: University of Georgia Press.

2017 by the author. Licensee MDPI, Basel, Switzerland. This article is an open access article distributed under the terms and conditions of the Creative Commons Attribution (CC BY) license (http:/ / creativecommons.org/licenses/by/4.0/). 